\title{
The effect of tides on dense water formation in Arctic shelf seas
}

\author{
C. F. Postlethwaite ${ }^{1}$, M. A. Morales Maqueda ${ }^{1}$, V. le Fouest ${ }^{2,}$, G. R. Tattersall ${ }^{1, * *}$, J. Holt ${ }^{1}$, and A. J. Willmott ${ }^{1}$ \\ ${ }^{1}$ National Oceanography Centre, Joseph Proudman Building, 6 Brownlow Street, Liverpool, L3 5DA, UK \\ ${ }^{2}$ The Scottish Association for Marine Science, Dunstaffnage Marine Laboratory, Oban, PA37 1QA, UK \\ * present address: Laboratoire d'Océanographie de Villefranche, BP 8 CNRS \& l'Université Pierre et Marie Curie (Paris VI), \\ 06238 Villefranche-sur-Mer Cedex, France \\ ** present address: Swathe Services, 1 Winstone Beacon, Saltash, Cornwall, PL12 4RU, UK
}

Received: 5 August 2010 - Published in Ocean Sci. Discuss.: 9 September 2010

Revised: 17 February 2011 - Accepted: 8 March 2011 - Published: 24 March 2011

\begin{abstract}
Ocean tides are not explicitly included in many ocean general circulation models, which will therefore omit any interactions between tides and the cryosphere. We present model simulations of the wind and buoyancy driven circulation and tides of the Barents and Kara Seas, using a $25 \mathrm{~km} \times 25 \mathrm{~km} 3$-D ocean circulation model coupled to a dynamic and thermodynamic sea ice model. The modeled tidal amplitudes are compared with tide gauge data and sea ice extent is compared with satellite data. Including tides in the model is found to have little impact on overall sea ice extent but is found to delay freeze up and hasten the onset of melting in tidally active coastal regions. The impact that including tides in the model has on the salt budget is investigated and found to be regionally dependent. The vertically integrated salt budget is dominated by lateral advection. This increases significantly when tides are included in the model in the Pechora Sea and around Svalbard where tides are strong. Tides increase the salt flux from sea ice by $50 \%$ in the Pechora and White Seas but have little impact elsewhere. This study suggests that the interaction between ocean tides and sea ice should not be neglected when modeling the Arctic.
\end{abstract}

\section{Introduction}

Tidal mixing is believed to play a significant role in maintaining abyssal stratification (Egbert and Ray, 2000; Munk and Wunsch, 1998) and in controlling the entire water column structure in continental shelf seas (e.g., Sharples et al., 2001; Rippeth, 2005). Thus, omitting tides from ocean general cir-

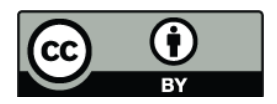

Correspondence to: C. F. Postlethwaite (cfpo@pol.ac.uk) culation models (OGCMs) presents a problem for many regions, including, as we shall see in the following, the Arctic Ocean and its shelf seas. Holloway and Proshutinsky (2007) have highlighted the problem of neglecting the effects of tidal mixing in regions of Atlantic inflow to the Arctic and the potential for underestimating ventilation of deep waters in these regions. Tidal mixing within the water column and at the base of the sea ice cover can increase the heat flow from deeper water masses towards the surface causing decreased freezing and increased melting of sea ice and possibly the formation of sensible heat polynyas (Morales-Maqueda et al., 2004; Willmott et al., 2007; Lenn et al., 2010). The tidal currents can additionally increase the stress and strain on the sea ice and cause leads to open periodically within the sea ice cover (Kowalik and Proshutinsky, 1994). The areas of open water exposed by such deformation of the sea ice are prone to intense winter heat loss (10-100 times larger than over sea ice, Maykut, 1982) and may in turn start to freeze, releasing salt to the underlying water as brine is rejected from the ice matrix. Although leads are not large (at most a few kilometers in width), their periodic tidal reoccurrence could mean that the dense water formed from rejected brine in leads is significant. In this paper we consider the impact of tides on sea ice cover and ocean stratification in an Arctic shelf sea region (Barents and Kara Seas) as simulated in a high-resolution regional OGCM.

Interactions between tides and sea ice are shown schematically in Fig. 1. Process 1 is the enhanced mixing by tides of surface waters with deeper, warmer water masses, which bring more heat into contact with the underside of the ice and increase melting or decrease the potential for freezing. Process 2 is the tidally induced mechanical opening of leads within the sea ice cover, which, in winter, leads to increased new ice production and hence increased brine

Published by Copernicus Publications on behalf of the European Geosciences Union. 


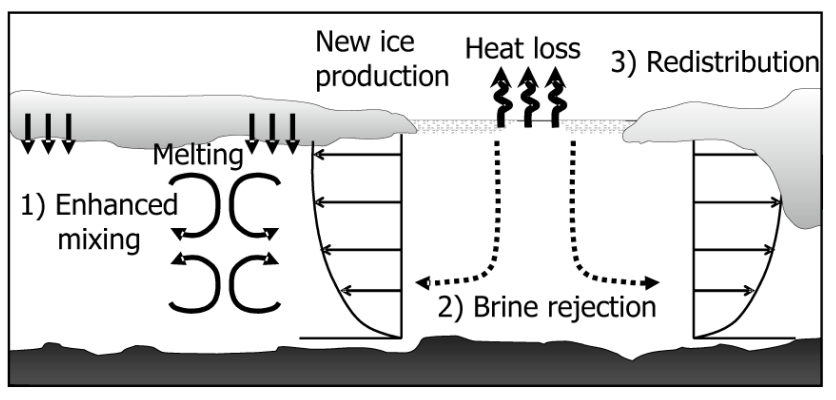

Fig. 1. Schematic highlighting the interaction between sea ice and tides.

rejection, whereas, in summer, it enhances the absorption of shortwave radiation by the oceanic mixed layer (Maykut and Perovich, 1987; Eisen and Kottmeier, 2000). Process 3 is the mechanical redistribution of ice itself caused by the alternation of convergence and divergence periods during the tidal cycle. A fourth process, not shown in the schematic, is tidal generation of residual currents and the associated ice drift.

In general, global climate models do not explicitly represent tides and high frequency oscillations. The horizontal resolution of climate models, such as those that contributed to the IPCC AR4 (Randall et al., 2007) are still too coarse $(\sim 110-220 \mathrm{~km})$ for tides to be appropriately captured in them. For example, a $200 \mathrm{~m}$ deep shelf sea at $75^{\circ} \mathrm{N}$ has a barotropic Rossby radius and M2 tidal wavelength of approximately $315 \mathrm{~km}$, requiring at least $\sim 100 \mathrm{~km}$ resolution. Besides, the typical frequency of atmosphere-ocean coupling of $\sim 24 \mathrm{~h}$ in IPCC-type models precludes the correct forcing of ocean tides. Muller et al. (2010) address this omission and find that explicitly including tides in the Max Planck Institute for Meteorology climate model (ECHAM5/MPI-OM) improves simulations of the climate in Western Europe.

Traditionally, OGCMs have also neglected tidal processes. In the past, the reason for this was simply that the rigid lid representation of the ocean surface used in most of these models did not allow tides to be included. At present, however, most OGCMs include a free surface and so can, in principle, accommodate tidal processes. Although model and computer advancement means that horizontal and vertical resolution are increasing in OGCMs such that the explicit inclusion of the barotropic tide is possible (Arbic et al., 2010; Thomas and Sündermann, 2001), they require substantial computer resources to run. Thus, regional models that can regularly operate on finer resolutions and shorter time steps are an efficient way to study tidal processes in Arctic shelf seas.

Holloway and Proshutinsky (2007) give a comprehensive review of previous high latitude tidal modeling studies so this is not repeated here. They also discuss two approaches to modeling the influence of tides in the Arctic Ocean, namely explicitly resolving the tides in a high resolution, threedimensional coupled ocean/ice model or parameterising their influence on sea ice and oceanic mixing in a coarser resolution model. In their paper, they follow the latter approach and include a parameterization of the influence of tides on sea ice and ocean in a coupled ice/ocean model with a rigid lid formulation of the ocean surface (the Arctic Ice/ocean Model AIM). Two tidally related processes are included in the Holloway and Proshutinsky (2007) study. Firstly, enhanced vertical mixing within the water column, which affects the freezing and melting rates of sea ice as relatively warm water is mixed towards the surface. Secondly, the area of open water in tidally active regions is increased to represent increased fracturing and ridging of sea ice by tides. Again, this has a feedback on the modeled sea ice cover as new ice can form in the freshly exposed areas of open water when atmospheric temperatures are cold enough. The forcing for these parameterizations are the time averaged total energy dissipation and time averaged water-column divergence provided by the barotropic tidal model of Kowalik and Proshutinsky (1994). Using this method, they complete a 1948-2005 integration of the sea ice-ocean system over the whole Arctic Ocean.

Rather than parameterising tidal effects on ocean mixing and sea ice motion, we explore in this paper the alternative method of explicitly modeling the leading tidal constituents in a three-dimensional coupled ocean/ice model, resolving the propagation of coastal trapped waves associated with tidal incursion on-shelf but not resolving the tidal excursion $(<7 \mathrm{~km})$. To do this we restrict ourselves to a $5 \mathrm{yr}$ regional model simulation of the Barents and Kara Seas (Fig. 2). These seas are some of the most important in the Arctic, with the Barents Sea dominating Arctic Ocean heat loss to the atmosphere (Serreze et al., 2007) and the Kara Sea receiving $\sim 55 \%$ of the river discharge into the Siberian Arctic (Pavlov and Pfirman, 1995). Warm Atlantic water undergoes intense cooling in the southern ice-free sector of the Barents Sea producing dense waters that may contribute to deep water formation in the Arctic (Rudels et al., 1994; Schauer et al., 2002). To the north and east, brine rejection from sea ice and polynya activity also contribute to dense water formation (Midttun, 1985). Tides are strong in the Barents Sea (the strongest in the Arctic apart from in the Canadian Arctic Archipelago, Padman and Erofeeva, 2004) and they play a significant role in dense water formation in the Arctic affecting stratification, circulation and sea ice.

\section{Model description}

For this study, we have coupled a state-of-the-art sea ice model to a three dimensional barotropic-baroclinic ocean model that includes the main tidal constituents in the Barents and Kara Seas. The ocean model is the Proudman Oceanographic Laboratory Coastal Ocean Modeling System (POLCOMS). POLCOMS is a sigma-coordinate, B-grid shelf sea model which has been tested extensively, particularly on the northwest European continental shelf (e.g. Siddorn et al., 
(a)

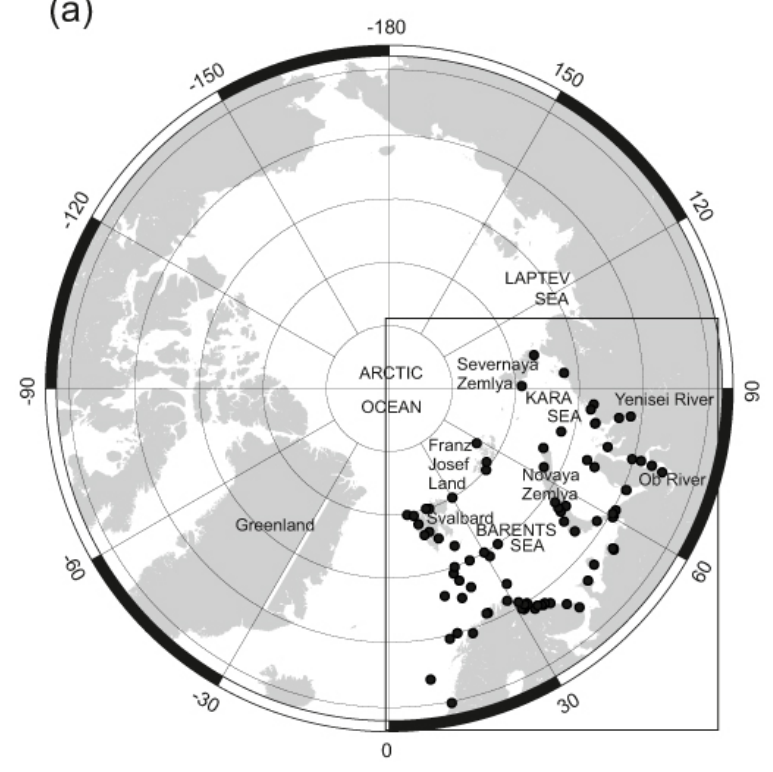

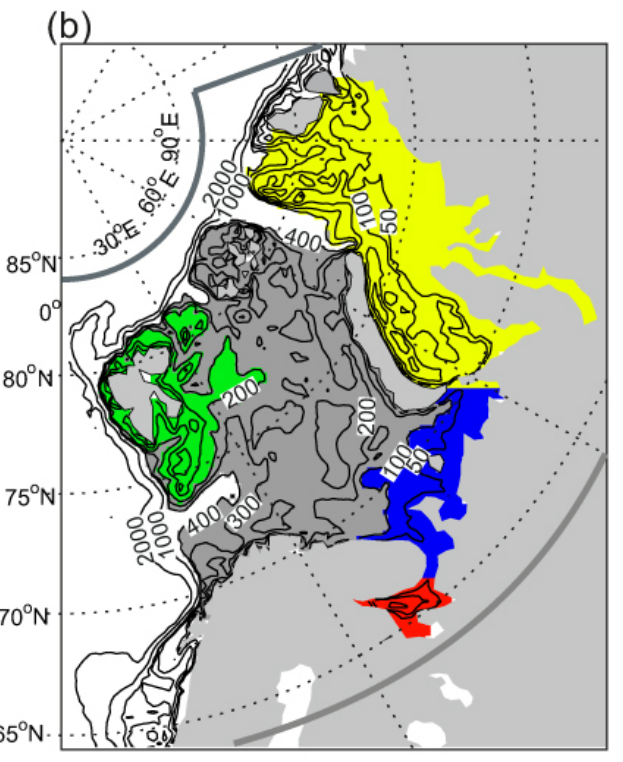

Fig. 2. (a) Polar stereographic projection of the Arctic showing the study region. Black dots indicate the location of tide gauges. (b) Bathymetry of the Barents and Kara Seas domain. The $400 \mathrm{~m}$ contour is taken to be the boundary of the continental shelf region. The grey line shows the edge of the model domain. Colors indicate subdomains used in this study (the Kara Sea is shaded yellow, the White Sea is red, the Pechora Sea is blue, the region around Svalbard is green and the rest of the Barents Sea is grey).

2007; Andreu-Burillo et al., 2007). The details of the model are well documented in Holt and James (2001). It suffices here to mention that the model uses a one equation variant of the Mellor and Yamada (1974) turbulence closure scheme to calculate vertical mixing, handles hydrostatic instabilities with an iterative convective adjustment method, and does not include explicit tracer horizontal diffusion (small amounts of numerical diffusion in the piecewise parabolic advection scheme used by the model guarantee tracer stability). Horizontal viscosity is held constant at $1.0 \times 10^{4} \mathrm{~m}^{2} \mathrm{~s}^{-1}$. POLCOMS has been coupled to the Los Alamos sea ice model (CICE v3.14, Hunke and Lipscomb, 2004). CICE is a multicategory dynamic-thermodynamic sea ice model that uses an elastic-viscous-plastic rheology. The simulations presented here use a single ice category to ease comparison with the previous tide/ice study of Holloway and Proshutinsky (2007). Ice/ocean heat fluxes are calculated using the standard mixed layer option in CICE, which has been adapted so that the ocean temperatures used in the calculations are the temperatures of the surface box of the ocean model. All other sea ice parameters are those described as standard in Hunke and Lipscomb (2004). The sea ice dynamics interacts with the tides via changes to the ice/ocean stress due to the tidal currents and residual circulation. The sea ice thermodynamics interacts with the tides via the ice/ocean heat fluxes. These are driven by the sea surface temperature which is affected by tidal mixing. The model does not include any representation of landfast ice.
The model domain has open boundaries to three sides, hence external forcing fields are required for both the ocean and ice models. These are discussed in Sect. 2.1 along with the surface forcing used. Both ocean and sea ice models are constructed on a grid defined using a Cartesian coordinate system (x, y) with the origin at the North Pole, the $\mathrm{x}$-axis in the direction of $90^{\circ} \mathrm{E}$ and a resolution of $25 \mathrm{~km}$ in both directions. This is similar to the coordinate system described in Gjevik and Straume (1989) but has the geometric scale factors associated with moving from a sphere to a Cartesian plain as constants. The domain spans $0^{\circ} \mathrm{E}-110^{\circ} \mathrm{E}$ and from $64^{\circ} \mathrm{N}-84^{\circ} \mathrm{N}$, with 109 grid points in the $\mathrm{x}$ direction and 141 in the y direction. The ocean model has 30 vertical depths defined using sigma levels, whereby the vertical spacing of the sigma levels are allowed to vary in the horizontal using the Scoordinate transform of Song and Haidvogel (1994), which allows higher resolution to be maintained near the surface in deep water. The time steps used are $10 \mathrm{~s}$ for the barotropic and $600 \mathrm{~s}$ for both the baroclinic and the ice model.

\subsection{Surface and boundary forcing}

Surface meteorological forcing is provided by the ERA40 reanalysis from the European Centre for Medium-Range Weather Forecasts (Uppala et al., 2005). Six hourly fields of 2-m atmospheric temperature, pressure at mean sea level, humidity, $10-\mathrm{m}$ wind velocity and cloud cover for the period 1 September 2000 to 31 August 2001 are used to calculate bulk surface fluxes (Holt and James, 2001 for the ocean 

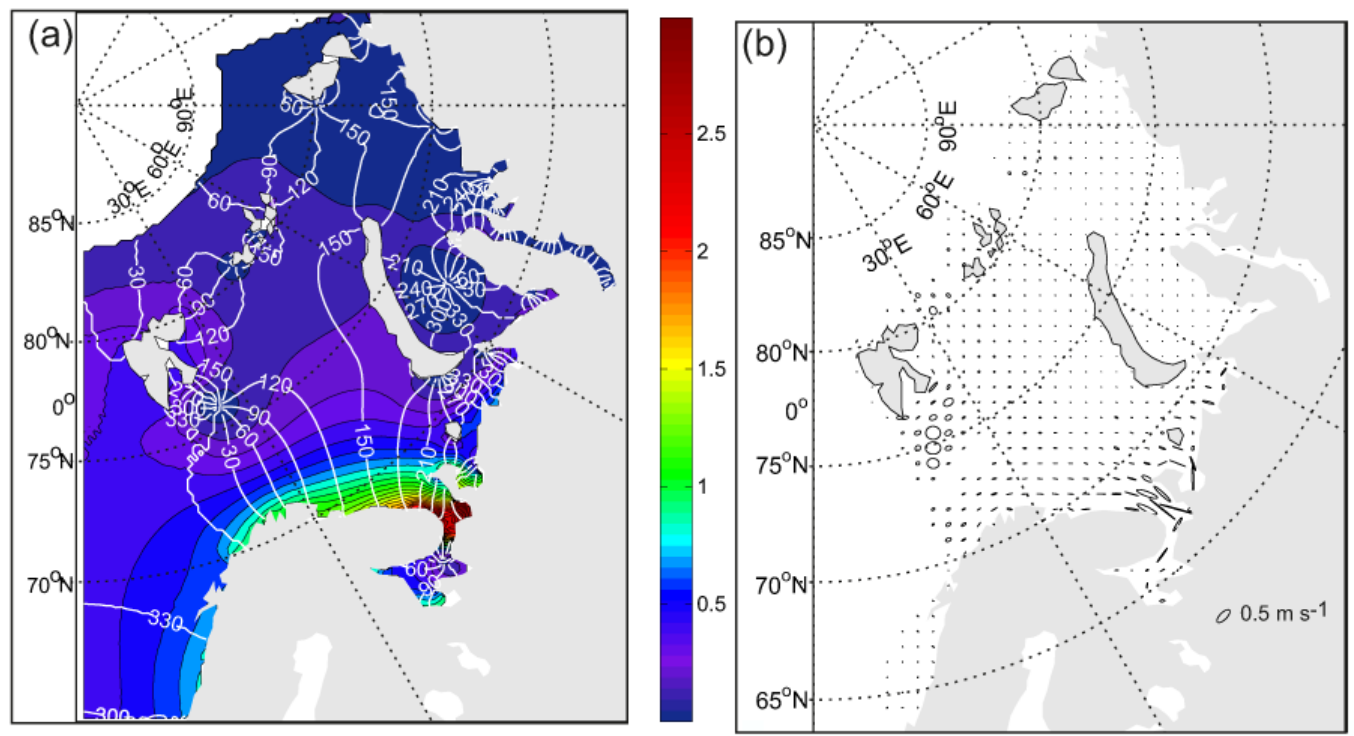

Fig. 3. (a) Contour plot of the M2 tidal elevation amplitude in meters (color with black contours. Contours are spaced every $0.1 \mathrm{~m}$ between 0 and $1 \mathrm{~m}$ and spaced every $0.5 \mathrm{~m}$ from $1-3 \mathrm{~m}$ ) and phase in degrees (white contours). (b) M2 tidal ellipses.

surface, and Hunke and Lipscomb, 2004 for the air-ice interface). A climatological annual cycle of precipitation for this area is created from the data of Serreze and Hurst (2000). Initial conditions for 1 September 2000 and lateral boundary conditions for the ocean component are derived from the US Navy Research Laboratory Naval Coastal Ocean Model (1/8 global NCOM with 40 vertical levels, Barron et al., 2006, 2007; Martin et al., 2004). Six hourly three-dimensional fields of temperature, salinity and ocean velocities for the same time period as the atmospheric forcing are linearly interpolated onto the model grid over a relaxation zone of width $100 \mathrm{~km}$ around the lateral boundaries as described in Holt and James (2001). Initial and six hourly boundary conditions for ice concentration and thickness are provided by the Polar Ice Prediction System (Preller and Posey, 1996; Woert et al., 2004) and interpolated onto the same relaxation zone. No restoring was applied to the domain interior. Sea surface elevations and velocities for tidal forcing at the open boundaries are sourced from the TPXO6.2 medium resolution global inverse tide model from Oregon State University (Egbert and Erofeeva, 2002) and are applied every barotropic time step. Eight tidal constituents are used: Q1, O1, P1, K1, N2, M2, S2 and T2. Freshwater input from the two largest rivers in the domain (the $\mathrm{Ob}$ and the Yenisei) are also included in the model. Daily values for the stream flow are created by averaging daily mean values from 1954-1999 for the river Ob and from 1955-1999 for the river Yenisei (GRDC, 2003).

\subsection{Model runs}

Results are presented here from two model runs, namely,

- Run 1 - POLCOMS/CICE without tides (control run)

- Run 2 - POLCOMS/CICE with tides.

In both cases, the model is integrated for $5 \mathrm{yr}$ repeating the atmospheric and oceanic forcing for the September 2000August 2001 period. Results from the last year of integration, when the sea ice cover is approaching a cyclostationary state, are analyzed here. By comparing the results from these two experiments we evaluate the impact of including tidal dynamics on the modeled ice distribution, ice formation and brine rejection.

\section{Results}

\subsection{Description of the modeled tides}

M2 is the main tidal constituent in this domain, comprising on average 0.8 of the total semidiurnal signal. The exception is around the Yermak Plateau where the diurnal constituents $\mathrm{O} 1$ and $\mathrm{K} 1$ dominate. Figure 3a shows the amplitude and phase of M2 elevation and Fig. 3b shows the M2 tidal ellipses. The maximum tidal range is found around the entrance to the White Sea, while the lowest amplitudes are found in the Kara Sea, which is largely in agreement with the high resolution simulations of the Arctic barotropic tide of Padman and Erofeeva (2004). M2 tidal currents are intensified on Svalbardbank to the south of Svalbard, the entrance to the White Sea and between Svalbard and Franz Josef 


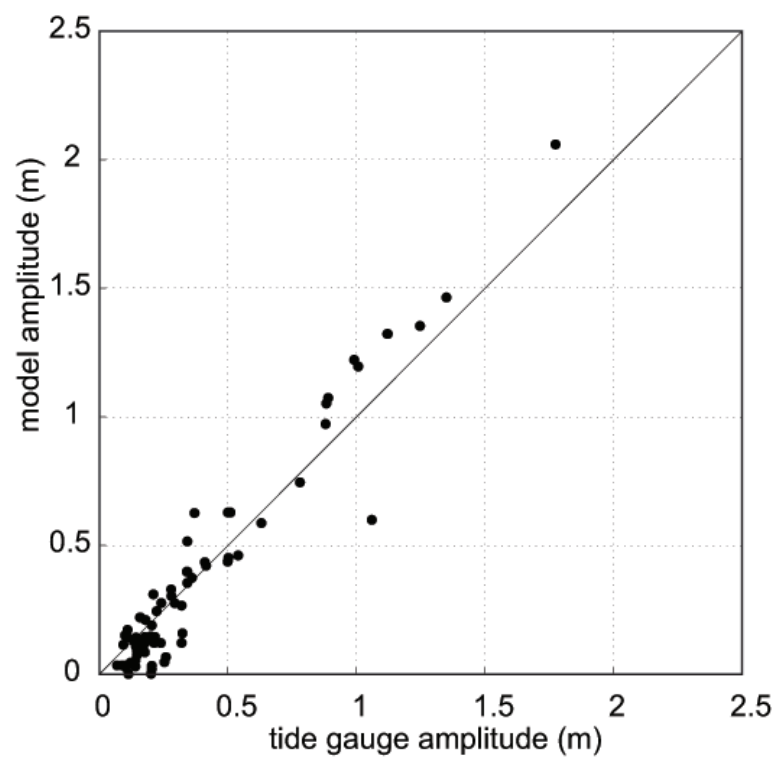

Fig. 4. Comparison of M2 model amplitude with tide gauge observations (Gjevik and Straume, 1989; IHO, 1994; Kowalik and Proshutinsky, 1994, 1995).

Land (Fig. 3b). Figure 4 shows a comparison of the modeled M2 tidal amplitude with historical tide gauge data (Gjevik and Straume, 1989; IHO, 1994; Kowalik and Proshutinsky, 1994, 1995). The agreement between the simulated and gauged tidal amplitudes is quite reasonable (RMS deviation $=12.1 \mathrm{~cm}$, mean deviation $=0.6 \mathrm{~cm}$ ) although the phase correspondence is not as good (RMS deviation $=43^{\circ}$, mean deviation $=6^{\circ}$ ). The tide gauge observations are predominantly from coastal locations (Fig. 1) and no extrapolation or interpolation of the modeled data has been done in the comparison; rather the model amplitude value at the grid point nearest to each tide gauge has been used. The simplicity of the approach along with the difficulty in modeling the propagation of coastal trapped waves around the complex coastline is most likely responsible for the differences between the modeled and observed tides.

\subsection{Impact of tides on sea ice distribution}

Assessing the impact of tides on sea ice distribution is complicated by the sometimes opposing interactions between tides and ice, as tides can increase melting at the base of the sea ice through enhanced diapycnal mixing of warm deep water with surface cold water, but can also promote new ice production by opening new leads where freezing occurs. Prior to pursuing this assessment, we initially examine how well the model reproduces the location of the sea ice edge, which is defined as the line of $15 \%$ ice concentration. The location of the sea ice edge at the time of maximum extent of the sea ice cover (March 2001) is comparable with remote sensing observations (Fig. 5). However, the sea ice edge location at the time of minimum ice extent (September) spreads somewhat southward of the observed one in the vicinity of Franz Josef Land (Fig. 5). Including tides in the model does not significantly improve the modeled ice extent in this region and the September ice edge remains to the south of the observed edge. The modeled sea surface temperature remains several degrees Centigrade cooler than coincident observations in the northern part of the Barents Sea during the summer (Ingvaldsen et al., 2002). It is unclear whether these discrepancies are a result of anomalous atmospheric forcing, to which sea ice is extremely sensitive (Hunke and Holland, 2007), or rather they reflect deficiencies in the model, bulk formulae, boundary conditions or a biased state of the ocean and sea ice following the $5 \mathrm{yr}$ spin up with repeat forcing from 2000-2001. In any case, these model errors do not unduly impact the present study into the interaction between tides and ice in our coupled ocean/sea ice model since the summer cold bias is present in both the control and tides simulations.

The net impact of including tides on the modeled sea ice distribution varies regionally. To investigate the spatial patterns of these changes the continental shelf region of the model domain has been divided into five subdomains defined by geographic and bathymetric boundaries. These subdomains are the White Sea, the Pechora Sea (shallower than $100 \mathrm{~m}$ ), the Kara Sea (shallower than $400 \mathrm{~m}$ ), the oceanic area around Svalbard (shallower than $200 \mathrm{~m}$ ) and the rest of the Barents Sea (shallower than $400 \mathrm{~m}$ ) (Fig. 2b). Time series of daily mean ice area and ice volume integrated over these five regions are plotted in Fig. 6a and c, respectively. The seasonal cycle of sea ice distribution in each subdomain differs widely and is in good agreement with satellite observations for all subdomains (Kern et al., 2010). The entire Kara Sea freezes rapidly during October and November and the ice continues to thicken until May. The Pechora and White Seas are ice free during the summer and freeze up occurs more gradually than in the Kara Sea. The area around Svalbard and the Barents Sea both retain ice in the summer months and have a gradual increase in sea ice during the winter.

The impact of including tides in the model on the sea ice area and volume varies between subdomains (Fig. $6 \mathrm{~b}$ and d), and so also do the causes for these variations. Warmer sea surface temperatures, caused by enhanced vertical mixing, delays freeze up in the Pechora Sea when tides are included in the model, such that approximately $30 \%$ less of the sea surface is ice covered during December and January. Without tides, haline stratification supports cooler water overlying warmer water, whereas including tides in the model causes warmer water to get mixed to the surface earlier in the year. The same process speeds up melting in the White Sea, where there is $30 \%$ less ice cover during the melting season when tides are included in the model. The actual changes in oceanic heat flux into the ice, however, are not very big, amounting to between 1 and $3 \mathrm{~W} \mathrm{~m}^{-2}$ and causing a decrease in ice thickness of only a few centimeters. Although small, 

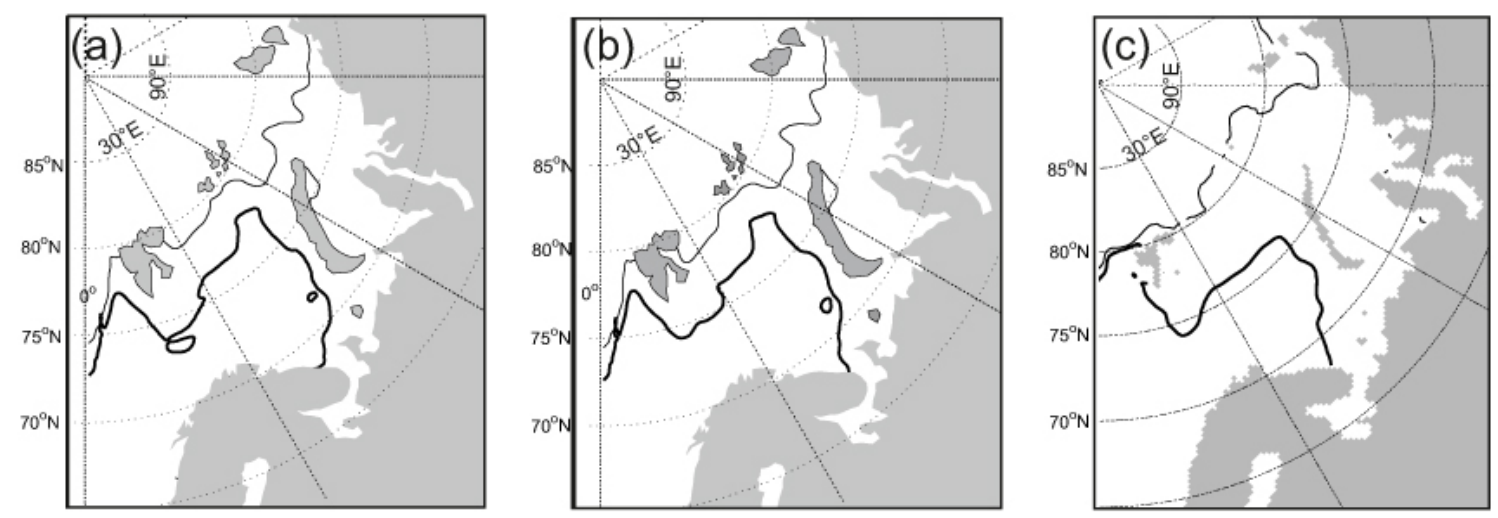

Fig. 5. Location of the ice edge when sea ice extent is at its' maximum and minimum for (a) the control run, (b) the run including tides and (c) from remote sensing of brightness temperatures data (Cavalieri et al., 1996, updated 2008). The thin lines show the monthly mean ice edge for September 2000 and the heavy lines show the monthly mean ice edge for March 2001. The ice edge is defined as the line of $15 \%$ concentration.
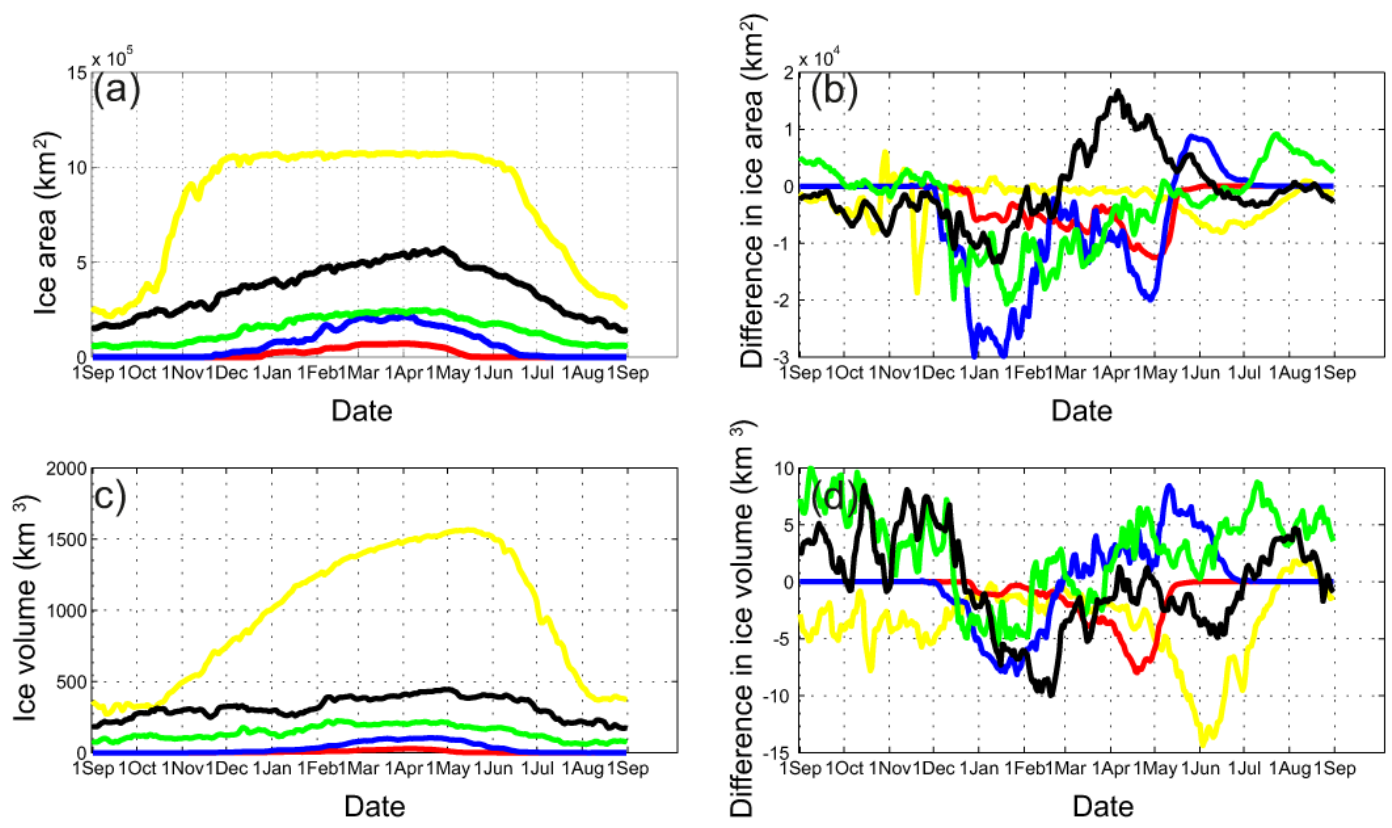

Fig. 6. (a) Daily ice area integrated over the subdomains shown in Fig. $2 b$ for the control model run. (b) Difference in ice area between the model run with and without tidal forcing integrated over each subdomain. Positive values indicate that the total ice area is greater with tidal forcing than without. (c) and (d) as above but for ice volume.

these oceanic heat flux anomalies are on the order of $10-20 \%$ of the net oceanic heat flux into the ice in the area. The area of open water within the sea ice (leads) increases by $50 \%$ in the Pechora Sea during March and April when tides are included in the model. Extra ice production ensues, resulting in a small increase in ice volume at this time $\left(\sim 2.5 \mathrm{~km}^{3}\right)$, with ice becoming an average of $5 \mathrm{~cm}$ thicker. Advection of ice in from the northern and western boundaries of the domain increases when tides are included in the model and cause ice to pile up around Svalbard, leading to a $5-10 \%$ increase in ice volume (Fig. 6d).
Changes to ice area affect the heat fluxes to and from the ocean but will only change the salt flux if they also cause differences in thermodynamic ice growth. Output from the sea ice model includes freezing and melting rates for each grid cell. These are integrated to give annual freezing and melting rates for each subdomain and for each model run (Tables 1 and 2). From the net freezing and melting balances, we can infer that the Pechora and Kara Seas are both net exporters of ice as less ice melts there than is formed in situ. Conversely, the area around Svalbard and the rest of the Barents Sea are net importers of ice, as more ice melts in these subdomains 
Table 1. Net freezing integrated over the subdomains indicated in Fig. $2 b$ for the model run with tides, the control run without tides and the differences between them $\left(\mathrm{km}^{3} \mathrm{yr}^{-1}\right)$. Also shown in brackets is the ice thickness increase brought about by this amount of net freezing when averaged over each subdomain $\left(\mathrm{m} \mathrm{yr}^{-1}\right)$.

\begin{tabular}{|c|c|c|c|}
\hline Net Freezing & $\begin{array}{l}\text { With tides } \\
\mathrm{km}^{3} \mathrm{yr}^{-1} \\
\left(\mathrm{~m} \mathrm{yr}^{-1}\right)\end{array}$ & $\begin{array}{l}\text { Without } \\
\text { tides } \\
\mathrm{km}^{3} \mathrm{yr}^{-1} \\
\left(\mathrm{~m} \mathrm{yr}^{-1}\right)\end{array}$ & $\begin{array}{l}\text { Difference } \\
\mathrm{km}^{3} \mathrm{yr}^{-1} \\
\left(\mathrm{~m} \mathrm{yr}^{-1}\right)\end{array}$ \\
\hline Pechora Sea & $\begin{array}{l}206 \\
(0.80)\end{array}$ & $\begin{array}{l}198 \\
(0.77)\end{array}$ & $\begin{array}{l}8 \\
(0.03)\end{array}$ \\
\hline Kara Sea & $\begin{array}{l}1154 \\
(1.16)\end{array}$ & $\begin{array}{l}1159 \\
(1.17)\end{array}$ & $\begin{array}{l}-5 \\
(0.01)\end{array}$ \\
\hline White Sea & $\begin{array}{l}39 \\
(0.55)\end{array}$ & $\begin{array}{l}39 \\
(0.55)\end{array}$ & $\begin{array}{l}0 \\
(0.00)\end{array}$ \\
\hline Svalbard & $\begin{array}{l}149 \\
(0.55)\end{array}$ & $\begin{array}{l}156 \\
(0.57)\end{array}$ & $\begin{array}{l}-7 \\
(-0.02)\end{array}$ \\
\hline Barents Sea & $\begin{array}{l}384 \\
(0.20)\end{array}$ & $\begin{array}{l}381 \\
(0.20)\end{array}$ & $\begin{array}{l}3 \\
(0.00)\end{array}$ \\
\hline Deep & $\begin{array}{l}869 \\
(0.68)\end{array}$ & $\begin{array}{l}909 \\
(0.72)\end{array}$ & $\begin{array}{l}-40 \\
(-0.04)\end{array}$ \\
\hline
\end{tabular}

than forms in situ. The deep region of the model domain that is not part of the continental shelf is dominated by melting but this area is heavily influenced by the boundary conditions and is not discussed further.

Including tides in the model increases net melting most significantly in the Svalbard region, where the tidal currents are strong. The impact on net freezing over the shelf varies from location to location with a small increase in freezing in the Pechora Sea and a small decrease around Svalbard. Although these differences correspond to relatively small volume changes in sea ice, the shallow depths of some coastal regions means that, as we shall see below, the influence on local salinity and density can be large.

\subsection{Impact of tides on salinity distribution}

Residual currents, tidal mixing and changes to brine rejection and sea ice melting all act to change the salinity distribution of the water column when tides are added to a coupled ocean/sea ice model. As a first attempt at establishing how tidal processes change the salinity distribution in the model, we compare the sea surface and sea bottom salinity (the salinity in the uppermost/lowermost model grid cells, respectively) between the two model runs for both winter and summer. Summer and winter mean sea surface and sea bottom salinity for the control model run are contoured in Fig. 7. The salty Norwegian Atlantic Current enters the domain at the southern open boundary. One branch, the North Cape Current, enters the Barents Sea following the Norwegian coastline. A second branch, the West Spitsber-
Table 2. Net melting integrated over the subdomains indicated in Fig. $2 b$ for the model run with tides, the control run without tides and the differences between them $\left(\mathrm{km}^{3} \mathrm{yr}^{-1}\right)$. Also shown in brackets is the ice thickness decrease brought about by this amount of net melting when averaged over each subdomain $\left(\mathrm{m} \mathrm{yr}^{-1}\right)$.

\begin{tabular}{|c|c|c|c|}
\hline Net melting & $\begin{array}{l}\text { With tides } \\
\mathrm{km}^{3} \mathrm{yr}^{-1} \\
\left(\mathrm{~m} \mathrm{yr}^{-1}\right)\end{array}$ & $\begin{array}{l}\text { Without } \\
\text { tides } \\
\mathrm{km}^{3} \mathrm{yr}^{-1} \\
\left(\mathrm{~m} \mathrm{yr}^{-1}\right)\end{array}$ & $\begin{array}{l}\text { Difference } \\
\mathrm{km}^{3} \mathrm{yr}^{-1} \\
\left(\mathrm{~m} \mathrm{yr}^{-1}\right)\end{array}$ \\
\hline Pechora Sea & $\begin{array}{l}155 \\
(0.60)\end{array}$ & $\begin{array}{l}153 \\
(0.59)\end{array}$ & $\begin{array}{l}2 \\
(0.01)\end{array}$ \\
\hline Kara Sea & $\begin{array}{l}1113 \\
(1.12)\end{array}$ & $\begin{array}{l}1117 \\
(1.13)\end{array}$ & $\begin{array}{l}-4 \\
(-0.01)\end{array}$ \\
\hline White Sea & $\begin{array}{l}38 \\
(0.53)\end{array}$ & $\begin{array}{l}40 \\
(0.56)\end{array}$ & $\begin{array}{l}-2 \\
(-0.03)\end{array}$ \\
\hline Svalbard & $\begin{array}{l}362 \\
(1.33)\end{array}$ & $\begin{array}{l}336 \\
(1.23)\end{array}$ & $\begin{array}{l}26 \\
(0.10)\end{array}$ \\
\hline Barents Sea & $\begin{array}{l}1063 \\
(0.56)\end{array}$ & $\begin{array}{l}1024 \\
(0.54)\end{array}$ & $\begin{array}{l}39 \\
(0.02)\end{array}$ \\
\hline Deep & $\begin{array}{l}6596 \\
(5.19)\end{array}$ & $\begin{array}{l}6423 \\
(5.05)\end{array}$ & $\begin{array}{l}173 \\
(0.14)\end{array}$ \\
\hline
\end{tabular}

gen Current, continues northward, tracking the continental slope. The salinity distribution of the Kara Sea is dominated by the large freshwater input from the $\mathrm{Ob}$ and Yenisei rivers (Fig. 2a). These rivers are frozen during the winter and reach their maximum outflow during the summer. Surface waters with a high volume of runoff from these two rivers flow northward through the Kara Sea, entering the eastern Barents Sea between Novaya Zemlya and Franz Josef Land and the Arctic Ocean between Franz Josef Land and Severnaya Zemlya (Fig. 7). Figure 8 shows the difference in sea surface and bottom salinity between the two model runs. Positive values indicate the grid point is more saline when tides are included in the model than in the control run. The key features of these plots are stated below and discussed in further detail in the next section. The dominant signal is the large positive salinity anomaly ( $>1 \mathrm{psu}$ ) along the Russian Coast from the White Sea in the southwest to the entrance to the Kara Sea in the northeast, which persists throughout the year and is found in both the surface model boxes and in the model grid cells closest to the seafloor (Fig. 8). In the Pechora Sea this anomaly is found only shoreward of the $50 \mathrm{~m}$ bathymetry contour. A series of positive and negative anomaly bands can be seen throughout the year in the surface waters of the Kara Sea and northeastern Barents Sea, in the vicinity of the river plumes from the $\mathrm{Ob}$ and Yenisei rivers (Fig. 8a and b). The coastal sector of the Kara Sea is saltier (by approximately $0.5 \mathrm{psu}$ ) when tides are included in the model. The waters surrounding Svalbard are consistently saltier throughout the water column when tides are included in the model. 

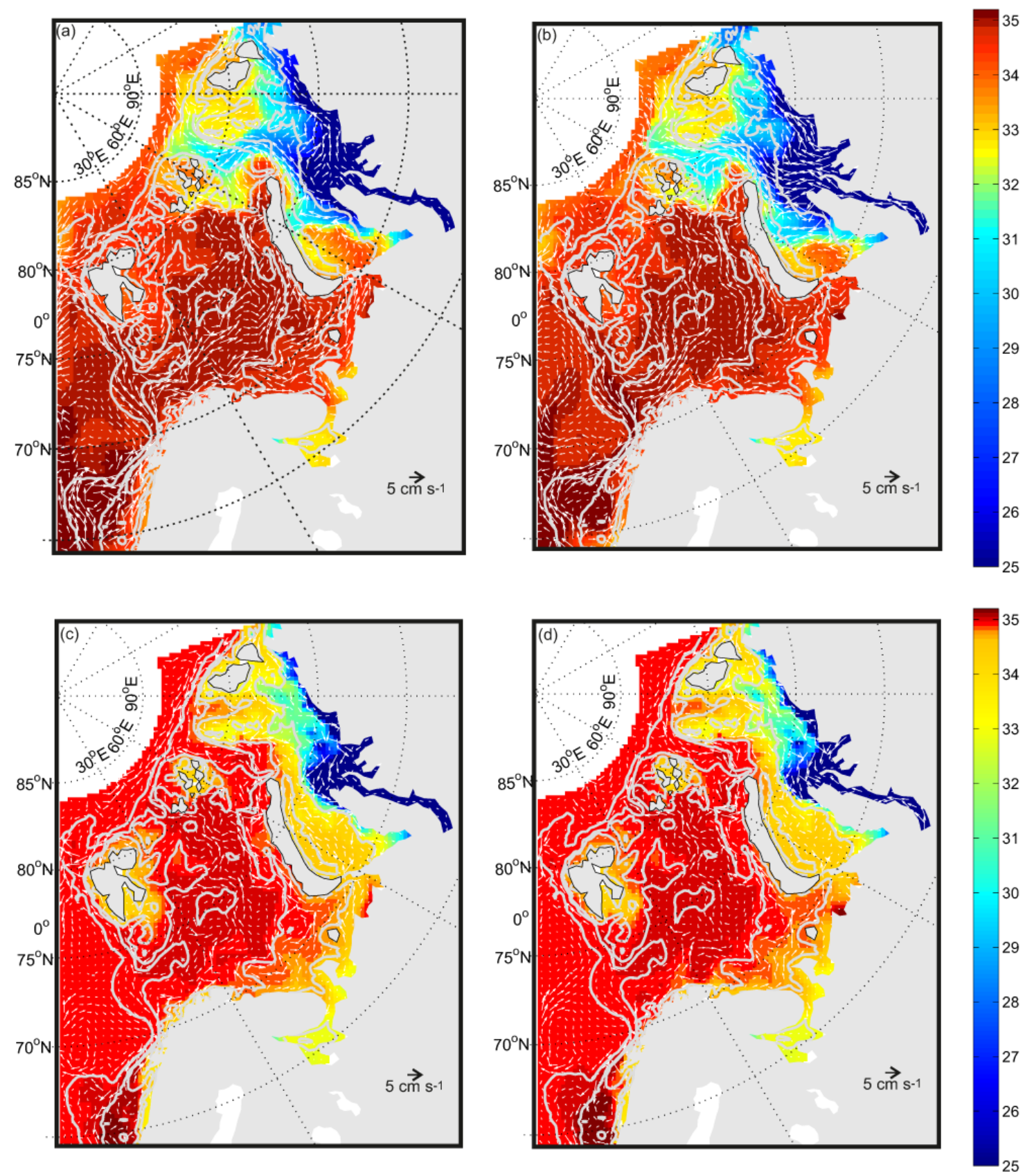

Fig. 7. Mean sea surface salinity (color contours) and velocity (arrows) for (a) winter and (b) summer from the fifth year of integration of the control model run (without tides). Mean sea bottom salinity (color contours) and velocity (arrows) for (c) winter and (d) summer from the fifth year of integration of the control model run (without tides). $50 \mathrm{~m}, 200 \mathrm{~m} 400 \mathrm{~m}$ and $1000 \mathrm{~m}$ bathymetric contours are shown. Winter is defined as December, January, February and summer is defined as June, July, and August. For clarity, the velocity vectors are capped at $5 \mathrm{~cm} \mathrm{~s}^{-1}$.

\section{Discussion}

We are interested in how tides affect dense water formation via brine rejection in the model. CICE does not include a formulation of salt release or entrapment upon ridging nor does the mixing scheme in POLCOMS account for additional stirring caused by sea ice fracture and pile up. As a result, mechanical redistribution of sea ice will not affect the salinity structure of the water column in the model unless it is accompanied by new ice forming or old ice melting. Any changes to thermodynamic ice growth could affect the salinity of the underlying water column, either by increasing salinity as brine is rejected during freezing or decreasing 

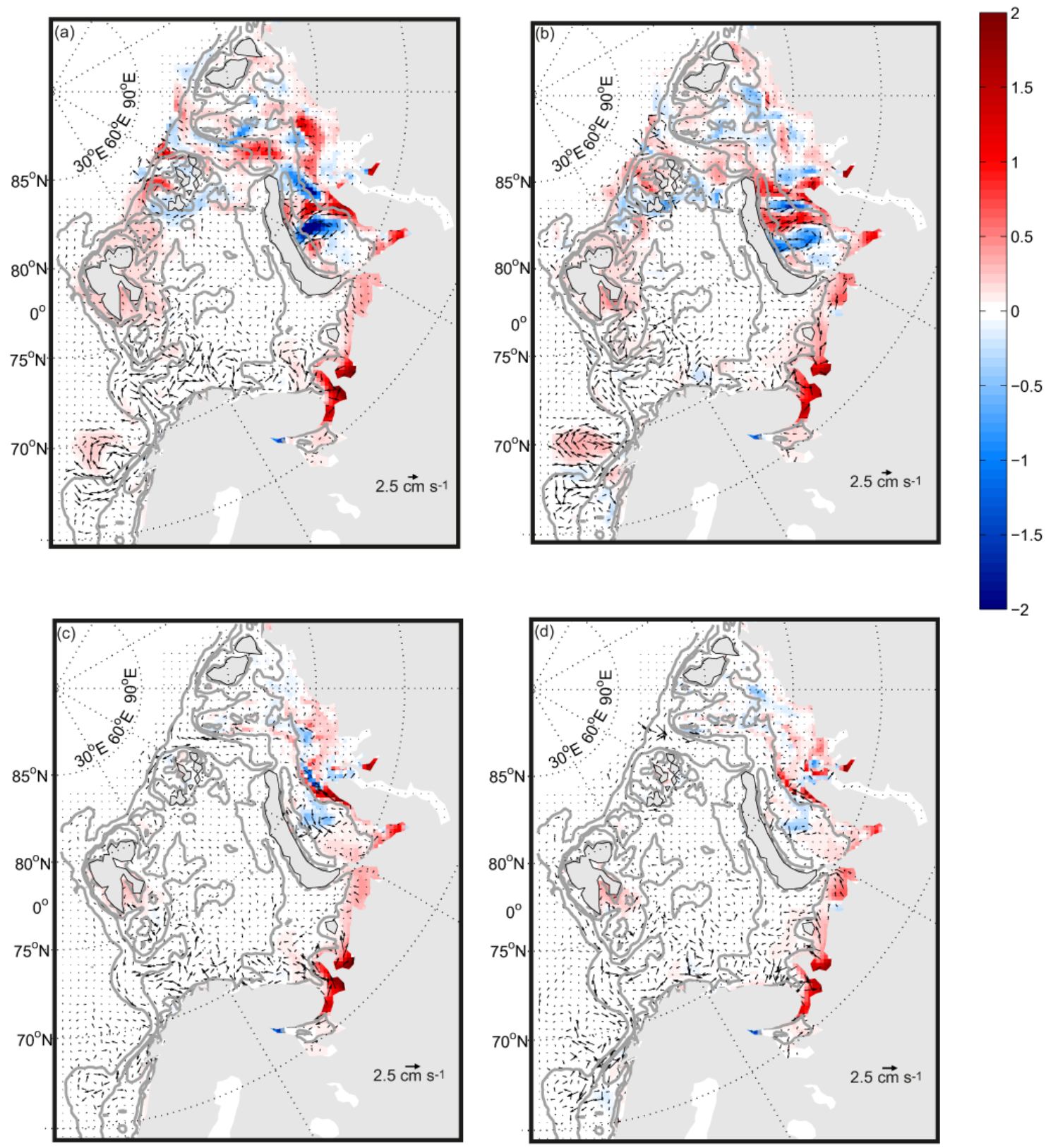

Fig. 8. Mean difference in sea surface salinity (color contours) and velocity (arrows) between the model run with tides and the control run for (a) winter and (b) summer from the fifth year of model integration. Mean difference in sea bottom salinity (color contours) and velocity (arrows) for (c) winter and (d) summer from the fifth year of model integration. Winter and summer as defined in Fig. 7 . Positive values indicate the salinity is greater when tides are included in the model. The velocity vectors are capped at $2.5 \mathrm{~cm} \mathrm{~s}^{-1}$.

salinity as freshwater is released during melting. Moreover, changes to the amount of open water will affect the surface freshwater fluxes by altering both the amount of evaporation that can occur and how much precipitation enters the ocean (in the model, snow falling on ice does not enter the ocean until the snow melts or ridging occurs, whereas precipitation falling directly into the ocean has an immediate effect on salinity). However, other processes affected by the tides may also act to change the salinity structure, for exam- ple tidally enhanced vertical or horizontal mixing of different water masses or salt transport by residual tidal currents. Here we discuss which of the changes to the water column salt budget are directly attributable to tide/ice interactions rather than other tidally related processes.

\subsection{Salt budget}

Figure $9 a$ and $b$ show the vertically integrated mass of salt per unit area for each point of the model domain on a logarithmic 

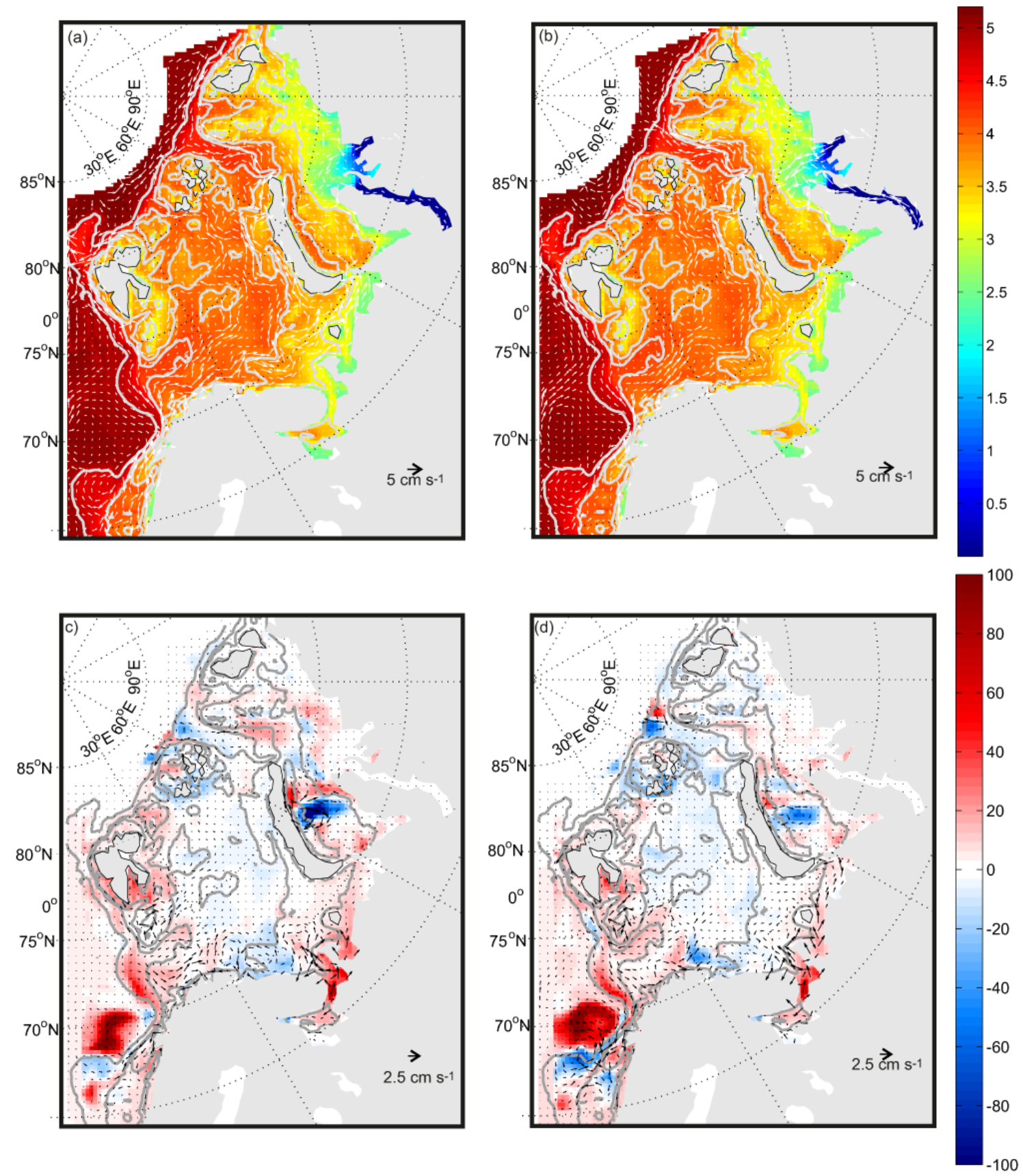

Fig. 9. Vertically integrated salt content $\left(\mathrm{kg} \mathrm{m}^{-2}\right.$, color contours on a logarithmic scale) and barotropic velocities (arrows) for (a) summer and (b) winter from the fifth year of integration of the control model run (without tides). The velocity vectors are capped at $5 \mathrm{~cm} \mathrm{~s}{ }^{-1}$. The difference in vertically integrated salt content $\left(\mathrm{kg} \mathrm{m}^{-2}\right.$, color contours) and barotropic velocities (arrows) between the model run with tides and the control run for (c) summer and (d) winter. The velocity vectors are capped at $2.5 \mathrm{~cm} \mathrm{~s}^{-1}$.

scale for both winter and summer. The distribution of this parameter is dominated by the water depth and there is therefore very little difference between the winter and summer plots. The lower panels in Fig. 9 show the difference in mean salt content between the run with and without tides. Red colors indicate a greater salt content when tides are in- cluded in the model. Large positive and negative salt anomalies at $70^{\circ} \mathrm{N}$ in the Norwegian Sea dominate these plots. These anomalies occur off of the continental shelf and are likely influenced by the open boundary. Including tides in the model also acts to increase the vertically integrated salt content along the continental slope between 70 and $74^{\circ} \mathrm{N}$ 
following the path of the Norwegian Atlantic Current. The western sector of the Barents Sea, including the area around Svalbard, contains more salt after five years when tides are included. In contrast, the eastern Barents Sea has less salt when tides are included in the model. The persistent positive salinity anomaly along the Russian coast seen in Fig. 8 is confirmed as a net increase in salt content (Fig. 9c and d). A complicated series of positive and negative salt anomalies are seen in the Kara Sea. However, tides do not cause significant changes to any of the net salt fluxes into or out of the Kara Sea, so these salt anomalies indicate small shifts in the circulation patterns within the Kara Sea.

Clearly, the salt distribution of the model run with tidal forcing differs from the one without tides. The following analysis looks at how the vertically integrated salt content of the water column evolves throughout the duration of the model run. Comparing model output before it reaches steady state allows us to monitor how the two model runs diverge and diagnose the causes. Salt budgets for each region described in Sect. 3.2 along with two further subdomains (the shallow Pechora Sea - shallower than $50 \mathrm{~m}$ and Storfjorden shallower than $100 \mathrm{~m}$ ) are shown in Fig. 10a-g. Each subplot contains thin lines representing data from the control run and thick lines representing data from the model run including tides. In some cases the results for the two experiments are very similar so only the thick lines are visible. The day to day change in mean salt content of the regions has been attributed to three sources; lateral transport, surface salt fluxes from ice covered regions (brine rejection, sea ice/snow melting and rain falling on ice) and surface salt fluxes from ice free regions (evaporation and precipitation over water). For clarity, we discuss each of these processes in turn.

\subsubsection{Lateral advection of salt}

Advection is the prime source or sink of salt in all shelf regions apart from the White Sea. Transport to the White Sea is restricted by a shallow channel which is only five grid cells wide, in contrast to the other subdomains which have long open boundaries across which salt can be advected. All subdomains, apart from the Kara Sea, gain salt by lateral transport during the five years of the experiment. Salt transport between subdomains reaches steady state within $3 \mathrm{yr}$ apart from in the Svalbard subdomain which is still gaining salt at the end of the five year run. Including tides in the model increases the mass of salt advected into the Pechora Sea and the Svalbard subdomains but the remaining regions show little change, reflecting the weakness of the tides there. Interestingly, in the Pechora Sea the mass of salt in the water column due to advection appears to be converging for the two model runs. Although the length of the model run does not allow us to confirm whether the salt transports from the two models do converge in this location, we suggest that including tides in the model decreases the time required to reach steady state for this parameter.

\subsubsection{Surface salt fluxes from ice free areas}

An imbalance between the amount of precipitation and evaporation over ice free areas is also an important contributor to the evolution of the salt budget of the model. These parameters are really freshwater fluxes but the POLCOMS model converts them to a salt flux and does not alter the water volume. The blue line in Fig. 10 shows the change to the mass of salt associated with evaporation and precipitation over open water or leads within the ice cover. A seasonal cycle can be seen in all five shelf regions but the signal is dominated by ongoing trends. Four of the subdomains have a negative trend meaning that locally, the seasonal cycle of precipitation is outstripping that of evaporation causing the water column to freshen. Including tides in the model makes little difference to the surface salt fluxes from ice free areas in any part of the model domain. As we saw in Sect. 3.2, including tides in the model leads to a decrease in ice concentration during the freeze up and melting season in the Pechora and White Seas. The associated increase in open water at these locations allows increased ice production which is partially compensated by an increase in precipitation directly entering the ocean.

\subsubsection{Surface salt fluxes from ice covered areas}

Surface fluxes from ice covered areas are the smallest component of the salt budget in all areas apart from the Pechora Sea, the White Sea and Storfjorden. Similarly to the way POLCOMS deals with evaporation and precipitation, POLCOMS/CICE converts the freshwater and salt fluxes associated with the growth and melting of sea ice into a salt flux with no associated change to water volume. The green line in Fig. 10 shows the mass of salt in the water column attributable to salt fluxes from ice covered regions. Salt increases in the water column during the winter as brine is rejected from newly forming ice and decreases in the summer as the ice and snow melt. In the White and Pechora Seas the annual cycle of salt sourced from ice covered regions is step shaped, with a large input of salt during freezing followed by a much smaller decrease of salt during melting. Including tides in the model increases the salt input by brine rejection significantly while making little change to the decrease in salt during melting. An increase in ice formation results when tidal divergence causes areas of open water to emerge within the ice pack. If atmospheric temperatures are sufficiently cold, rapid freezing can ensue accompanied by salt rejection and an increase in the density of the water column. The salt flux from new ice in the model depends on how much ice forms. In addition to these two areas where freezing exceeds melting, there is a third site of fairly enhanced sea ice growth in Storfjorden, southern Svalbard, a well documented area of dense water formation (Ivanov et al., 2004). Although the tides are relatively strong around Svalbard, they have little effect on thermodynamic ice production when integrated over 

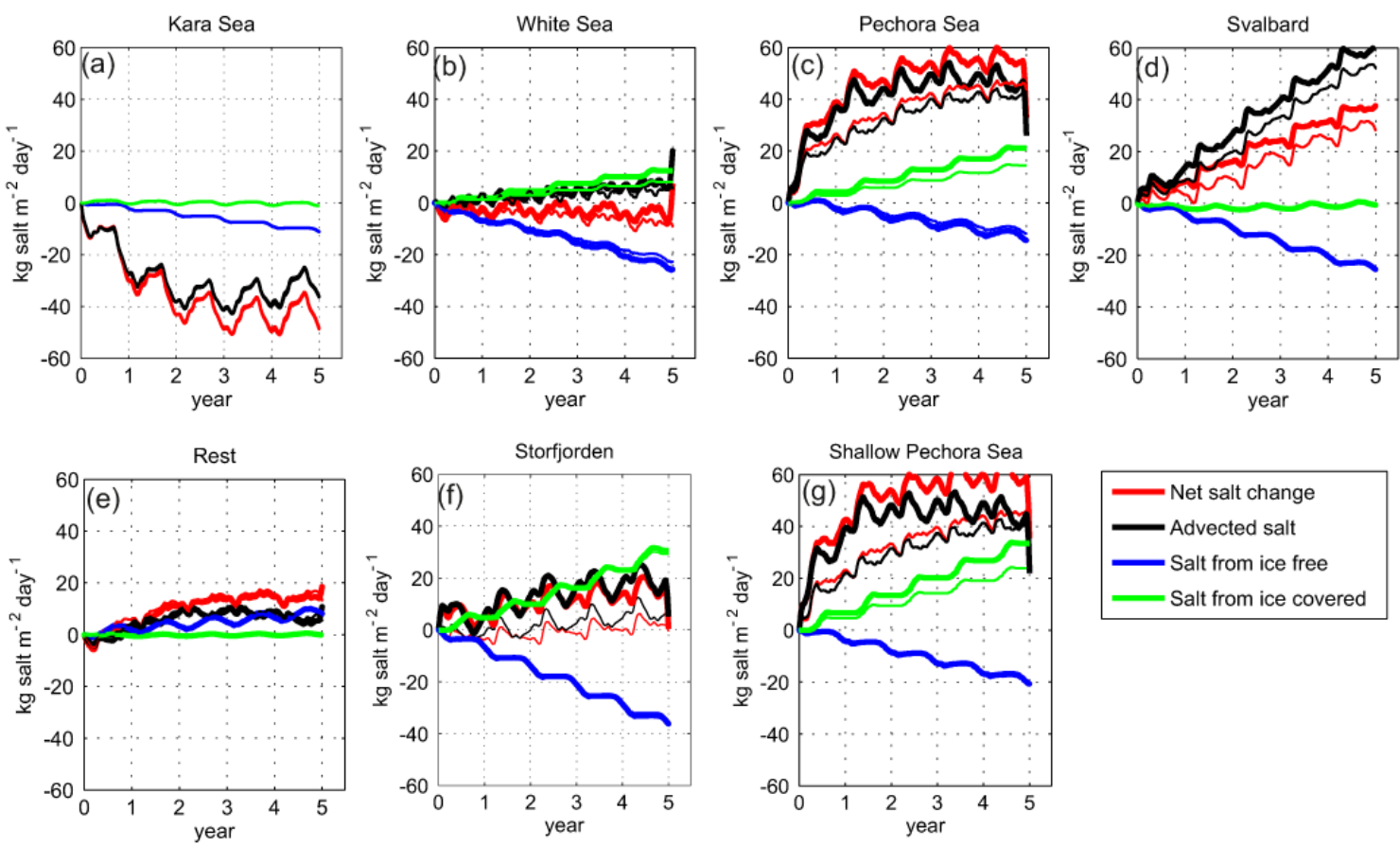

Fig. 10. Time series of the change in vertically integrated salt content $\left(\mathrm{kg} \mathrm{salt} \mathrm{m}^{-2}\right.$ ) relative to the initial salt content, $S_{0}$ (red). Daily means have been spatially averaged over the five subdomains shown in Fig. $2 \mathrm{~b}$ and two additional subdomains; Storfjorden and the shallow Pechora Sea. The contribution to vertically integrated salt content from lateral advection (black), surface fluxes from ice free regions (blue) and surface fluxes from ice covered regions (green) are also shown. Thick lines show results from the model run including tides and thin lines are from the control run. A thirty day running mean has been applied to remove high frequency variation and highlight the trends. Initial values are $S_{0}=2714 \mathrm{~kg} \mathrm{~m}^{-2}$ (Kara Sea), $1811 \mathrm{~kg} \mathrm{~m}^{-2}$ (White Sea), $1379 \mathrm{~kg} \mathrm{~m}^{-2}$ (Pechora Sea), $3883 \mathrm{~kg} \mathrm{~m}^{-2}$ (Svalbard), $7862 \mathrm{~kg} \mathrm{~m}^{-2}$ (Barents Sea), $771 \mathrm{~kg} \mathrm{~m}^{-2}$ (Storfjorden) and $708 \mathrm{~kg} \mathrm{~m}^{-2}$ (shallow Pechora Sea).

the whole Svalbard subdomain. Indeed, the tidally induced change to salt content in this region is primarily due to an increase in the lateral advection of salt (Fig. 10d). However, when the domain is limited to the Storfjorden region, brine rejection clearly forms a major component of the salt budget (Fig. 10f). Brine rejection does not change significantly with the addition of tides in this location.

As mentioned above, the model predicts that the Pechora Sea is a net exporter of ice, which is transported into the Barents Sea by the western Novaya Zemlya Current along the western coast of Novaya Zemlya (Panteleev et al., 2007) and the Kara Sea through the Kara Gate. This excess sea ice formation and export in the Pechora Sea provides a positive contribution to the annual salt budget of the region in both the tides and no-tides experiments but is stronger in the former run. Tides cause a residual current to flow from the entrance to the White Sea around the Kanin Peninsula (Fig. 8). This residual current could be due to tidal rectification or density driven by the increased salinity at the Kanin Peninsula. During the summer this current extends all the way along the coast of the Pechora Sea to the entrance to the Kara Sea but is reduced in the winter. There is no change to the Novaya Zemlya Current with the inclusion of tides.
The part of the model where tides cause the most significant increase in salt due to excess brine rejection is the Pechora Sea. The details of the salt budget analysis presented here are sensitive to the location of the subdomain boundaries. It was noted in Sect. 3.3 that the salinity increase in the Pechora Sea was most prominent shoreward of the $50 \mathrm{~m}$ bathymetric contour. The salt budget for this shallow sector of the Pechora Sea reveals that the large tidally induced increase in salinity here is driven primarily by increased brine rejection (Fig. 10g). This region acts as a brine factory exporting ice and brine to the adjacent Pechora Sea and beyond.

\section{Summary and conclusions}

Although including tides in this regional coupled sea ice/ocean model does not significantly change the sea ice budget over the whole model domain, it does affect the sea ice distribution and processes on smaller scales. The impact of tides on sea ice is not straightforward, with some areas exhibiting an increase in thermodynamic ice production (Pechora Sea) and some a decrease (around Svalbard). Most regions in this model study exhibited an increase in annual melting rates when tidal forcing was included in the model. 
However, only the more tidally active sites, the Pechora Sea and the White Sea, saw a significant delay in freezing and a speed up of ice retreat during the melting season. Koentopp et al. (2005) also reached a similar conclusion in their modeling study of tide/ice interaction in the Weddell Sea. Although including tides in the model leads to an increase in ice volume around Svalbard for most of the year, this is not formed in situ but is advected in from outside. Hence there is no associated brine rejection signal associated with it.

Although we have not made any attempt to quantify whether including tides in the model better represents oceanographic observations, it is clear that omitting any representation of them from models will neglect many important physical processes. Parameterising tide-ice interactions such as in Holloway and Proshutinsky (2007) is a computationally efficient way to proceed if fully resolving the tides is not possible. However, the parameterization described by Holloway and Proshutinsky (2007) does not capture the effects of increased horizontal mixing or residual currents that we found to be significant in this study. Moreover, tides can create strong vertical current shear that increases vertical mixing, thus homogenizing the water column and bringing warm, saline Atlantic water towards the surface. This important process is represented in our model but is not discussed in the salt budget analysis as it has no net effect on the vertically integrated salt content.

In this study we have investigated whether the interaction between tides and sea ice has an impact on brine rejection. Two locations, the White and Pechora Seas, are key sites where brine rejection increases by $50 \%$ when tides are included in the model. Landfast ice is not represented in this study so it is likely that polynyas caused by offshore winds occur closer to the coast in these simulations than in ones which do include landfast ice. Locating the ice producing polynyas in more tidally active regions closer to the coast may mean the effect of tides on brine rejection is overestimated in this study. However, as the band of landfast ice is relatively narrow in the Pechora Sea it seems likely that the region would be a key site of enhanced brine rejection due to tide ice interaction irrespective of the presence of land fast ice. What distinguishes these two sites from other shallow, tidally active locations is not clear. They do stand out as locations where adding tides to the model significantly reduces the mixing parameter $h / U^{3}$ (where $h$ is the water depth and $U$ is the depth mean current), indicating enhanced mixing (Simpson and Hunter, 1974). Hannah et al. (2009) used this parameter in the Canadian Arctic Archipelago to identify recurrent sensible heat polynyas that are influenced by tidal currents. It is likely that there are other similar sites across the Arctic where increased brine rejection occurs due to tide/ice interaction.
Acknowledgements. This work was funded by the UK Natural Environment Research Council Strategic Research Programme Oceans 2025 and Thematic Programme RAPID, via Grant NER/T/S/2002/00979. We would like to thank Pam Posey and Lucy Smedstad from the Naval Research Laboratory for assistance in supplying NCOM and PIPS data for the boundary conditions for this study. ERA-40 data was kindly supplied by the European Centre for Medium-Range Weather Forecasts. We appreciate the comments of John Huthnance, Adrian Turner and an anonymous reviewer that greatly enhanced the paper.

Edited by: M. Hecht

\section{References}

Arbic, B. K., Wallcraft, A. J., and Metzger, E. J.: Concurrent simulation of the eddying general circulation and tides in a global ocean model, Ocean Model., 32, 175-187, 2010.

Andreu-Burillo, I., Holt, J., Proctor, R., Annan, J. D., James, I. D., and Prandle, D.: Assimilation of sea surface temperature in the POL Coastal Ocean Modelling System, J. Marine Syst., 65, 2740, 2007.

Barron, C. N., Kara, A. B., Martin, P. J., Rhodes, R. C., and Smedstad, L. F.: Formulation, implementation and examination of vertical coordinate choices in the Global Navy Coastal Ocean Model (NCOM), Ocean Model., 11, 347-375, 2006.

Barron, C. N., Kara, A. B., Rhodes, R. C., Rowley, C., and Smedstad, L. F.: Validation Test Report for the 1/8 Global Navy Coastal Ocean Model Nowcast/Forecast System, NRL Report NRL/MR/7320-07-9019, Stennis Space Center, MS, 2007.

Cavalieri, D., Parkinson, C., Gloersen, P., and Zwally, H. J.: Sea ice concentrations from Nimbus-7 SMMR and DMSP SSM/I passive microwave data, (September 2000, March 2001) Boulder, Colorado USA: National Snow and Ice Data Center, Digital media, 1996, updated 2008.

Egbert, G. D. and Erofeeva, S. Y.: Efficient inverse modeling of barotropic ocean tides, J. Atmos. Ocean. Tech., 19, 183-204, 2002.

Egbert, G. D. and Ray, R. D.: Significant dissipation of tidal energy in the deep ocean inferred from satellite altimeter data, Nature, 405, 775-778, 2000.

Eisen, O. and Kottmeier, C.: On the importance of leads in sea ice to the energy balance and ice formation in the Weddell Sea, J. Geophys. Res.-Oceans, 105, 14045-14060, 2000.

Gjevik, B. and Straume, T.: Model simulations of the M2 and the K1 tide in the Nordic Seas and the Arctic Ocean, Tellus, 41A, 73-96, 1989.

GRDC: River discharge data 1954-1999, Global Runoff Data Centre, Koblenz, 56068 Germany, 2003.

Hannah, C. G., Dupont, F., and Dunphy, M.: Polynyas and Tidal Currents in the Canadian Arctic Archipelago, Arctic, 62, 83-95, 2009.

Holloway, G. and Proshutinsky, A.: The role of tides in Arctic ocean/ice climate, J. Geophys. Res., 112, C04S06, doi:10.1029/2006JC003643, 2007.

Holt, J. and James, I. D.: An s-coordinate density evolving model of the northwest European continental shelf 1, Model description and density structure, J. Geophys. Res., 106, 14014-14034, 2001. 
Hunke, E. C. and Holland, M. M.: Global atmospheric forcing data for Arctic ice-ocean modeling, J. Geophys. Res., 112, C04S14, doi:10.1029/2006JC003640, 2007.

Hunke, E. C. and Lipscomb, W. H.: CICE: the Los Alamos sea ice model, documentation and software user's manual, LA-CC98-16 v.3.1, Los Alamos National Laboratory, Los Alamos, New Mexico, 2004.

IHO: IHO Tidal Constituent Bank, Special publication No. 50, 1994.

Ingvaldsen, R., Loeng, H., and Asplin, L.: Variability in the Atlantic inflow to the Barents Sea based on a one-year time series from moored current meters, Cont. Shelf Res., 22, 505-519, 2002.

Ivanov, V. V., Shapiro, G. I., Huthnance, J. M., Aleynik, D. L., and Golovin, P. N.: Cascades of dense water around the world ocean, Prog. Oceanogr., 60, 47-98, 2004.

Kern, S., Kaleschke, L., and Spreen, G.: Climatology of the Nordic (Irminger, Greenland, Barents, Kara and White/Pechora) Seas ice cover based on $85 \mathrm{GHz}$ satellite microwave radiometry: 1992-2008, Tellus A, 62A, 411-434, 2010.

Koentopp, M., Eisen, O., Kottmeier, C., Padman, L., and Lemke, P.: Influence of tides on sea ice in the Weddell Sea: Investigations with a high-resolution dynamic-thermodynamic sea ice model, J. Geophys. Res., 110, C02014, doi:10.1029/2004JC002405, 2005.

Kowalik, Z. and Proshutinsky, A. Y.: The Arctic Ocean tides, in: The polar oceans and their role in shaping the global environment: the Nansen centennial volume, edited by: Johannessen, O. M., Muench, R. D., and Overland, J. E., 525 pp., 1994.

Kowalik, Z. and Proshutinsky, A. Y.: Topographic enhancement of tidal motion in the western Barents Sea, J. Geophys. Res., 100, 2613-2637, 1995.

Lenn, Y.-D., Rippeth, T. P., Old, C. P., Bacon, S., Polyakov, I., Ivanov, V., and Hölemann, J.: Intermittent intense turbulent mixing under ice in the Laptev Sea Continental Shelf, J. Phys. Oceanogr., doi:10.1175/2010JPO4425.1, in press, 2010.

Martin, S., Polyakov, I., Markus, T., and Drucker, R.: Okhotsk Sea Kashevarov Bank polynya: Its dependence on diurnal and fortnightly tides and its initial formation, J. Geophys. Res.-Oceans, 109, C09S04, doi:10.1029/2003JC002215, 2004.

Maykut, G. A.: Large-Scale Heat-Exchange and Ice Production in the Central Arctic, J. Geophys. Res.-Oc. Atm., 87, 7971-7984, 1982.

Maykut, G. A. and Perovich, D. K.: The Role of Shortwave Radiation in the Summer Decay of a Sea Ice Cover, J. Geophys. Res.-Oceans, 92, 7032-7044, 1987.

Mellor, G. L. and Yamada, T.: Hierarchy of Turbulence Closure Models for Planetary Boundary-Layers, J. Atmos. Sci., 31, 1791-1806, 1974.

Midttun, L.: Formation of dense bottom water in the Barents Sea, Deep-Sea Res., 32, 1233-1241, 1985.

Morales-Maqueda, M. A., Willmott, A. J., and Biggs, N. R. T.: Polynya Dynamics: A review of observations and modeling, Rev. Geophys., 42, RG1004, doi:10.1029/2002RG000116, 2004.

Muller, M., Haak, H., Jungclaus, J. H., Sündermann, J., and Thomas, M.: The effect of ocean tides on a climate model simulation, Ocean Model., 35, 304-313, 2010.

Munk, W. and Wunsch, C.: Abyssal Recipes II: energetics of tidal and wind mixing, Deep-Sea Res. Pt. I, 45, 1977-2010, 1998.

Padman, L. and Erofeeva, S.: A barotropic inverse tidal model for the Arctic Ocean, Geophys. Res. Lett., 31, L02303,
doi:10.1029/2003GL019003, 2004.

Panteleev, G., Proshutinsky, A., Kulakov, M., Nechaev, D. A., and Maslowski, W.: Investigation of the summer Kara Sea circulation employing a variational data assimilation technique, J. Geophys. Res.-Oceans, 112, C04S15, doi:10.1029/2006JC003728, 2007.

Pavlov, V. K. and Pfirman, S. L.: Hydrographic structure and variability of the Kara Sea: Implications for pollutant distribution, Deep-Sea Res. Pt. II, 42, 1369-1390, 1995.

Preller, R. H. and Posey, P. G.: Validation Test Report for a Navy Sea Ice Forecast System: The Polar Ice Prediction System 2.0. NRL Report NRL/FR/7322-95-9634, Stennis Space Center, MS, 1996.

Randall, D. A., Wood, R. A., Bony, S., Colman, R., Fichefet, T., Fyfe, J., Pitman, A., Shukla, J., Srinivasan, J., Stouffer, R. J., Sumi, A., and Taylor, K. E.: Climate Models and their Evaluation, in: Climate Change 2007 - The Physical Science Basis. Contribution of Working Group I to the fourth Assessment Report of the Intergovernmental Panel on Climate Change, edited by: Solomon, S., Qin, D., Manning, M., Chen, Z., Marquis, M., Averyt, K. B., Tignor, M., and Miller, H. L., Cambridge University Press, Cambridge, United Kingdom and New York, NY, USA, 2007.

Rippeth, T.: Mixing in seasonally stratified shelf seas: a shifting paradigm, Philos. T. R. Soc. A, 363, 2837-2854, 2005.

Rudels, B., Jones, E. P., Anderson, L. G., and Kattner, G.: On the Intermediate Depth Waters of the Arctic Ocean, in: The Polar Oceans and Their Role in Shaping the Global Environment, Geophysical Monograph 85, edited by: Johannessen, O. M., Muench, R. D., and Overland, J. E., AGU, Washington, 33-46, 1994.

Schauer, U., Loeng, H., Rudels, B., Ozhigin, V. K., and Dieck, W.: Atlantic Water flow through the Barents and Kara Seas, DeepSea Res. Pt. I, 49, 2281-2298, 2002.

Serreze, M. C. and Hurst, C. M.: Representation of mean Arctic precipitation from NCEP-NCAR and ERA reanalyses, J. Climate, 13, 182-201, 2000.

Serreze, M. C., Barrett, A. P., Slater, A. G., Steele, M., Zhang, J., and Trenberth, K. E.: The large-scale energy budget of the Arctic, J. Geophys. Res., 112, D11122, doi:10.1029/2006JD008230, 2007.

Sharples, J., Moore, C. M., and Abraham, E. R.: Internal tide dissipation, mixing, and vertical nitrate flux at the shelf edge of NE New Zealand, J. Geophys. Res., 106, 14069-14081, 2001.

Siddorn, J. R., Allen, J. I., Blackford, J. C., Gilbert, F. J., Holt, J. T., Holt, M. W., Osborne, J. P., Proctor, R., and Mills, D. K.: Modelling the hydrodynamics and ecosystem of the North-West European continental shelf for operational oceanography, J. Marine Syst., 65, 417-429, 2007.

Simpson, J. H. and Hunter, J. R.: Fronts in the Irish Sea, Nature, 250, 404-406, 1974.

Song, Y. H. and Haidvogel, D.: A Semi-implicit Ocean Circulation Model Using a Generalized Topography-Following Coordinate System, J. Comput. Phys., 115, 228-244, 1994.

Thomas, M. and Sündermann, J.: Consideration of ocean tides in an OGCM and impacts on subseasonal to decadal polar motion excitation, Geophys. Res. Lett., 28, 2457-2460, 2001.

Uppala, S. M., Kållberg, P. W., Simmons, A. J., Andrae, U., da Costa Bechtold, V., Fiorino, M., Gibson, J. K., Haseler, J., Hernandez, A., Kelly, G. A., Li, X., Onogi, K., Saarinen, S., Sokka, N., Allan, R. P., Andersson, E., Arpe, K., Balmaseda, M. A., 
Beljaars, A. C. M., van de Berg, L., Bidlot, J., Bormann, N., Caires, S., Chevallier, F., Dethof, A., Dragosavac, M., Fisher, M., Fuentes, M., Hagemann, S., Hólm, E., Hoskins, B. J., Isaksen, L., Janssen, P. A. E. M., Jenne, R., McNally, A. P., Mahfouf, J.-F., Morcrette, J.-J., Rayner, N. A., Saunders, R. W., Simon, P., Sterl, A., Trenberth, K. E., Untch, A., Vasiljevic, D., Viterbo, P., and Woollen, J.: The ERA-40 re-analysis, Q. J. Roy. Meteor. Soc., 131, 2961-3012, 2005.
Willmott, A. J., Holland, D. M., and Morales Maqueda, M. A.: Polynya modeling, in: Polynyas: Windows to the World, edited by: Smith Jr., W. O. and Barber, D. G., Elsevier, Oxford, (Elsevier Oceanography Series, 74) 87-125, 2007.

Woert, M. L. W., Zou, C. Z., Meier, W. N., Hovey, P. D., Preller, R. H., and Posey, P. G.: Forecast Verification of the Polar Ice Prediction System (PIPS) Sea Ice Concentration Fields, J. Atmos. Ocean. Tech., 21, 944-957, 2004. 